\title{
Social identification factors of managers and entrepreneurs
}

\author{
Evgeniia Lazukova*, and Guzel Seletkova \\ Perm National Research Polytechnic University, 29, Komsomolsky ave., Perm, 614990, Russia
}

\begin{abstract}
The social identification of managers is divided into deep and shallow. The authors give the comparative analysis of the social identification of managers and entrepreneurs through its types, as well as through the determination of these types by various factors. Among entrepreneurs, the shares of those who have and those who do not have a conscious, deep identification with their social and professional group are approximately the same. The same situation is among managers. In addition, the authors studied the influence of gender, age, material situation, level of education, secondary employment and other factors on the determined types. Gender does not affect these types of social identification. The real factors also include the additional work, age, the use of competencies, satisfaction with the results of activities and membership in professional associations.
\end{abstract}

\section{Introduction}

The scientific literature examines the impact of institutional [1] and cultural [2] differences on the development of entrepreneurship. Akerlof and Kranton [3] introduce the concept of identity into the function of economic effectiveness. Identity plays an important role in the explanation of the motivation to choose entrepreneurial activity with the subsequent influence on the economic future of a person [4].

The strategic business decisions are determined by a personality of an entrepreneur, his reaction to changes, therefore, the identity of entrepreneurs is important for the survival of business $[5,6,7,8,9,10,11]$. An entrepreneur and an enterprise arise as a function of constant experience, while an enterprise creates an entrepreneur, as an entrepreneur creates an enterprise [12]. Thus, it is necessary to note the importance of the personality of an entrepreneur and social identity and identification in particular.

There are scientific studies that reveal the connection between the social identification of entrepreneurs by various motives and results of entrepreneurial activity $[13,14,15,16,17,18]$, with the way of thinking [19] and the meaningfulness of entrepreneurial experience [20, 21]. The start of your own business involves changing roles and building the identity of the role of a founder of a company $[22,23]$. Scientists also note the importance of the study of identity not only as fixed characteristics, but also as a process and its mechanism [24].

Some researchers note that entrepreneurs, when starting and running a business, try on different roles that become a part of their identity. During the study of the process of the choice of a role and formation of an identity, three mechanisms are distinguished: "the perception of an entrepreneur as a person who "takes off his hats", the discovery of a new meaning (new role identity) within the enterprise and imprinting of role identity" [25].

\section{Materials and Methods}

The process of identification with a professional group can be deep or shallow. Our empirical sociological research among leaders and entrepreneurs in Perm conducted in 2019-2020 showed what it depends on.

The social identification of these two groups was divided into formal (shallow, associated with mentioning a profession/position only to a direct question about it) and into a conscious one (deep, where a profession/position is also mentioned in the answer to the question: "Who am I?"). In accordance with this, 4 types of respondents were singled out according to social identification: "formal leader", "perceived leader", "formal entrepreneur" and "perceived entrepreneur".

We made an attempt to find out the influence of various factors on the identification of managers and entrepreneurs comparing these two socio-professional groups.

\section{Results and Discussion}

The analysis of the research results did not reveal the influence of th gender of respondents on the type of social identification. However, the influence of other socio-demographic and socio-economic factors was revealed (Table 1).

According to the research data, as the professional experience increases, the share of the type of "perceived manager" grows (from 27 to 40\%) and the share of the type of "formal entrepreneur" decreases (from 20 to $13 \%$ ). The proportions of the remaining types do not significantly depend on professional experience. 
Table 1. Influence of various factors on the types of social identification (in\%).

\begin{tabular}{|c|c|c|c|c|}
\hline Factors & 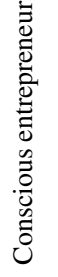 & 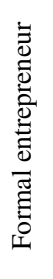 & 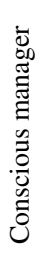 & 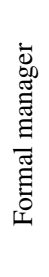 \\
\hline \multicolumn{5}{|l|}{ Gender } \\
\hline Male & 32 & 19 & 30 & 19 \\
\hline Female & 37 & 16 & 33 & 14 \\
\hline \multicolumn{5}{|l|}{ Age } \\
\hline Up to 39 years old & 28 & 13 & 38 & 21 \\
\hline 40 and older & 43 & 19 & 28 & 10 \\
\hline \multicolumn{5}{|c|}{ Professional experience } \\
\hline Up to 5 years & 36 & 20 & 27 & 17 \\
\hline Over 5 years & 31 & 13 & 40 & 16 \\
\hline \multicolumn{5}{|l|}{ Education } \\
\hline Secondary & 40 & 20 & 20 & 20 \\
\hline Vocational secondary education & 50 & 22 & 16 & 12 \\
\hline $\begin{array}{l}\text { Higher education and incomplete higher } \\
\text { education }\end{array}$ & 30 & 17 & 36 & 17 \\
\hline \multicolumn{5}{|l|}{ Marital status } \\
\hline Married (including unregistered marriage) & 34 & 19 & 34 & 13 \\
\hline Not married & 33 & 14 & 30 & 23 \\
\hline \multicolumn{5}{|c|}{ Secondary employment } \\
\hline ...is present & 28 & 18 & 34 & 18 \\
\hline ...is not present & 42 & 17 & 28 & 13 \\
\hline \multicolumn{5}{|c|}{ Professional associations } \\
\hline ...members & 20 & 20 & 20 & 40 \\
\hline ...not members & 35 & 17 & 33 & 15 \\
\hline \multicolumn{5}{|c|}{ Satisfaction with the results of their activities } \\
\hline ...satisfied & 36 & 18 & 33 & 13 \\
\hline ...not satisfied & 29 & 18 & 21 & 32 \\
\hline \multicolumn{5}{|c|}{ In case of other sources of income } \\
\hline ...agree to work & 24 & 9 & 38 & 29 \\
\hline ...not agree to work & 38 & 21 & 30 & 11 \\
\hline \multicolumn{5}{|l|}{ Job... } \\
\hline $\begin{array}{l}\ldots \text { interesting and important, regardless of } \\
\text { payment }\end{array}$ & 39 & 17 & 36 & 8 \\
\hline $\begin{array}{l}\ldots \text { - is important, but there are things much } \\
\text { more interesting than work }\end{array}$ & 31 & 14 & 32 & 23 \\
\hline$\ldots$ is the main source of living & 33 & 21 & 29 & 17 \\
\hline \multicolumn{5}{|l|}{ Competences... } \\
\hline ...are being realized & 33 & 17 & 33 & 17 \\
\hline$\ldots$ are not being realized & 0 & 50 & 33 & 17 \\
\hline \multicolumn{5}{|l|}{ Attitude towards a profession } \\
\hline A profession is the best or one of the best & 35 & 12 & 34 & 19 \\
\hline $\begin{array}{l}\text { A profession is neither better nor worse than } \\
\text { others }\end{array}$ & 31 & 22 & 31 & 15 \\
\hline A profession is worse than others & 67 & 0 & 33 & 0 \\
\hline \multicolumn{5}{|c|}{ Attitude to market conditions } \\
\hline Negative & 24 & 6 & 29 & 41 \\
\hline Neutral & 24 & 23 & 35 & 18 \\
\hline Positive & 42 & 15 & 32 & 11 \\
\hline \multicolumn{5}{|c|}{ Attitude towards a role of state } \\
\hline $\begin{array}{l}\text { State assistance to one degree or another is } \\
\text { allowed }\end{array}$ & 41 & 21 & 19 & 19 \\
\hline $\begin{array}{l}\text { State assistance to one degree or another is } \\
\text { not allowed }\end{array}$ & 31 & 16 & 38 & 15 \\
\hline \multicolumn{5}{|l|}{ Succeed in the professional field, ... } \\
\hline $\begin{array}{l}\text {... considering laws, goals of business and } \\
\text { employees }\end{array}$ & 31 & 17 & 34 & 18 \\
\hline ... using any means & 44 & 22 & 25 & 9 \\
\hline \multicolumn{5}{|c|}{ The decision of your children to go into business } \\
\hline ...would be approved & 36 & 16 & 30 & 18 \\
\hline ... would not be approved & 12 & 15 & 58 & 15 \\
\hline$\ldots$ is found difficult to answer & 52 & 19 & 19 & 10 \\
\hline
\end{tabular}

The level of education has some influence on the studied types. Among those with a low level of education (among those who graduated from school or college/technical school), the most common type is the "conscious entrepreneur" (40 and 50\%, respectively). At the same time, among those who have got or are getting higher education, the most popular type is the "conscious mamnager" (there are more than a third of them - 36\%).

The absence of marriage increases the chances of getting into the "formal leader" type. In relation to other types of social identification, the influence of marital status was not revealed.

Secondary employment has some influence on the studied types. The presence of additional work significantly increases the chances of getting into the type of " conscious entrepreneur" (from 28 to 42\%) and slightly reduces the chances of getting into the type of " conscious manager" (from 34 to $28 \%$ ).

Table 1 also presents the influence of membership in professional associations on the types of social identification. Membership in professional associations reduces the share of «perceived» types (from about 35 to $20 \%$ ), and also more than doubles or increases the share of «formal types » within the statistical error (of the «formal manager » type from 15 to $40 \%$ and of the « formal entrepreneur » from 17 to $20 \%$ ).

The satisfaction with the results of their activities affects the characteristics of the identification of managers and entrepreneurs. It has a beneficial effect on social identification, because it increases the possibility to transform into "conscious" types when the "formal" types are reduced or unchanged.

Among those willing to work in the presence of other sources of income, the most common type is a "conscious manager" (38\%); among those who do not agree to work in this case, the type of "conscious entrepreneur" is most widely represented (38\%); this, apparently, refers to the high importance of the material side of labor for conscious type, which is less typical for those who are identified as a manager.

During the study of attitudes towards work, influencing the types of social identification, some patterns are determined. The types that have a stable identification with the socio-professional group ("conscious entrepreneur" and " conscious manager") demonstrate not so strong, but rather stable dependence on the factor. These typological groups among respondents who are interested in work and emphasize the importance of work are the most representative (a concious entrepreneur - $39 \%$ and a concious manager $36 \%$ ) in comparison with similar groups of respondents who have a different attitude to work (there are things that are much more interesting than work $-31 \%$ and $32 \%$, respectively; work is a source of living - 33\% and $29 \%$, respectively).

Whereas the respondents who belong to the typological groups «formal entrepreneur» and «formal manager », on the contrary, are more inclined to demonstrate their attitude to work as a source of income (21\% and $17 \%$, respectively) in comparison with similar groups of respondents with a different attitude to work (there are things that are much more interesting than 
work - $14 \%$ and $23 \%$, respectively; work is interesting and important $-17 \%$ and $8 \%$, respectively).

These patterns can be interpreted as the evidence of a more pronounced terminal labor motivation (in comparison with instrumental motivation) in typological groups with a deeper social identification ("conscious entrepreneur" and "conscious manager"). Typological groups with shallow social identification ("formal entrepreneur" and "formal manager"), on the contrary, have a greater tendency towards instrumental labor motivation (in comparison with terminal motivation).

The types of identification are associated with the implementation of existing competencies. In the group of those who implement their existing competences (knowledge, skills, and abilities) in their profession, "concious entrepreneurs/ managers" prevail (one third or each type); while among those who do not their competences, the type "formal entrepreneur" dominates (it presents a half). Consequently, a deeper identification with an entrepreneur and a manager is associated with the application of their knowledge, skills, and possessions.

The contradictory results are revealed during the study of the influence of such a factor as attitude to the profession on the types of social identification. Among the respondents who have a positive or neutral attitude to their profession, there are practically no fluctuations in the representativeness of typological groups. The exception is the typological group of "formal entrepreneurs", which is more representative in the case of a neutral assessment of their profession than a positive one $(22 \%$ and $12 \%$, respectively).

However, there is a significantly larger share of the type of "conscious entrepreneur" among respondents who have a negative assessment of their profession $(67 \%)$ in comparison with those who have a neutral $(31 \%)$ and positive $(35 \%)$ assessment. It is assumed that such a shift in the assesments should be regarded not as evidence of a stable trend, but as an isolated case due to the small number of respondents who have a negative attitude to their profession, which makes these patterns statistically insignificant. In this case, individual representatives of the typological group show a pronounced instrumental motivation, since, under the condition of clear negative attitude towards their profession, the respondents demonstrate a stable identification with their social group.

According to the results of our research, the types of the considered identification are determined by the relation to market conditions. Those representatives with a negative attitude to the market are mainly refer to the type of "formal manager" (41\%); as a rule, the carriers of a neutral attitude are the representatives of the "concious manager" type (35\%).

It is necessary to note that among those who positively relate to market conditions in Russia, the representatives of the "concious entrepreneur" type prevail $(42 \%)$, which is explicable both from the point of view of objective dependence, the possibility and efficiency of running a business on the level of development of market relations and above mentioned dependence, which shows that the type of conscious entrepreneur is the most representative among the respondents with the highest level of well-being.

Among the respondents who believe that the state assistance to its citizens is permissible, the type of "conscious entrepreneur" prevails twice over other types $(41 \%)$. We think that this feature of Russian entrepreneurship in many respects contradicts the specifics of its activities related to the readiness to take initiative. Among the supporters of the responsibility of citizens themselves (not state) for the life and well-being of an individual, the type of "concious mamager" has a greater value $(38 \%)$.

We can assume that the presence of this regularity in the type «concious manager» can be explained by the strong connection of this type with such characteristics as diligence (Pearson's correlation coefficient 0.74); the ability to find a common language with other people (coefficient 0.72); as well as the average relationship with assessments of organization (coefficient 0.68); selfconfidence (coefficient 0.66 ); the ability to lead people (coefficient 0.61). Thus, the representatives of this typological group probably place greater responsibility on a person than on the state.

There are different types of respondents among those who have different ways to achieve success in their professional sphere. The modal group among those who use any means to achieve their goals in the professional sphere is the type of "conscious entrepreneur" (44\%). Among those who are not ready to " stop at nothing," 2 types prevail, represented by about a third: "a conscious manager" and "a conscious entrepreneur" (34 and 31\%, respectively). Moreover, among those who claim that they achieve their goals by any available means, the proportion of types of «entrepreneurs » is greater, and on the contrary the types of «managers» are less. Apparently, an unconditional orientation towards success is more typical of businessmen, including against a particular individual. Among those who responded positively to the question of the hypothetical decision of their children to become entrepreneurs (as well as among those who found it difficult to answer this question), the most common type was the "conscious entrepreneur" (36 and 52\%, respectively). In the first group, it seems that these are entrepreneurs who are satisfied with their professional activities, and in the second group are those who find advantages and disadvantages in it.

Most of the representatives of the "conscious manager" type would not approve the attitude of their children towards this question. Apparently, the rejection of entrepreneurship led them to management activities. It is worth noting that shallow identification of the type of "formal entrepreneurs" significantly reduces their share among those who would approve the decision of children to do business (from 36 to $16 \%$ ) and among those who have not formed an opinion on this issue (from 52 to $19 \%)$.

At the same time, Oliver notes that the formation of entrepreneurial identity must begin at an early age, since the entrepreneurial characteristics of parents and peers have a significant impact on the formation of identity [4]. 


\section{Conclusions}

In the activity of a manager, his identification with a professional group plays a special role. According to the study, the following conclusions can be drawn.

The additional work and secondary employment changes the proportion of types with deep identification: for entrepreneurs it increases, for managers it decreases. The increase in age slightly affects the depth of identification as it increases the proportion of types of entrepreneurs, while reducing the proportion of types of managers. Membership in professional associations increases shallow identification with one or another social and professional group and the use of competencies and satisfaction with the results of activities increases deep identification.

\section{References}

1. S. Estrin, T. Mickiewicz. Small Business Economics. 37, 4, (2011). doi: 10.1007/s11187011-9373-0

2. R. Shinnar, O. Giacomin, F. Janssen Entrepreneurship Theory and Practice. 36(3), 465494. (2012). doi: 10.1111/j.15406520.2012.00509.x.

3. G.A. Akerlof, R.E. Kranton. Quarterly Journal of Economics. 105(3), 715-53. (2000)

4. O. Falck, S. Heblich, E. Lüdemann CESifo Working Paper Series. 2661. (2009)

5. E. Fauchart, M. Gruber. Academy of Management Journal, 54(5), 35-57. (2011)

6. L. N. Chaplin, D. R. John. Journal of Consumer Research, 32(1), 119-129. (2005)

7. M. Levy, P. Powell. Strategies for growth in SMEs: The role of information and information systems. (Oxford, UK: Information Systems Series (ISS), Elsevier, 2005)

8. R. K. Singh, S. K. Garg, S. G. Deshmukh Benchmarking: An International Journal, 15(5), 525-547. (2008)

9. D. Vargas, R. G.-T. Rangel Technological Forecasting and Social Change, 74(1), 90-99. (2007)

10. E. E. Powell, T. Baker Academy of Management Journal, 57(5), 1406-1433. (2014)

11. C. Slade. Creating a brand identity: A guide for designers. (London, UK: Laurence King Publishing, 2016)

12. M. H. Morris, D. F. Kuratko, M. Schindehutte, A. J. Spivack. Entrepreneurship: Theory and Practice, 36(1), 11-40. (2012)

13. G.A. Alsos, T.H. Clausen, U. Hytti, S. Solvoll. Entrepreneurship \& Regional Development, 28(3), 234-258. (2016)

14. M.E. de la Cruz, A.J.Verdú Jover, J.M. Gómez Gras. European Research on Management and Business Economics, 24(2), 90-96 (2018

15. M. Gruber, E. Fauchart. Academy of Management Journal, 54(5) (2011)
16. J. Musona, K. Puumalainen, H. Sjögrén, A. Vuorio. MDPI, Open Access Journal, 13(2), 1-37 (2021)

17. Ph. Sieger, M. Gruber, E. Fauchart, T. Zellweger. Journal of Business Venturing, 31(5), 542-572 (2016)

18. M. S. Cardon, J. Wincent, J. Singh, M. Drnovsek. Academy of Management Review, 34(3), 511-532 (2009)

19. R. Korte. Advances in Engineering Education, 7(1) (2018)

20. S. Korhonen, T. Leppäaho. Journal of International Entrepreneurship, 17(3), 355-388 (2019)

21. P. Gregori, P. Holzmann, M.A. Wdowiak. Journal of Business Research, 122(C), 488-501 (2021)

22. H. Hoang, J. Gimeno. Journal of Business Venturing, 25(1), 41-53 (2010)

23. M. Cardon, D. Gregoire, C.E. Stevens, P. C. Patel. Journal of Business Venturing, 28(3), 373-396 (2013)

24. C. M. Leitch, R. T. Harrison Entrepreneurship \& Regional Development, Taylor \& Francis Journals, 28(3-4), 177-190 (2016)

25. B. D. Mathias, D. W. Williams Journal of Business Venturing, 33(3), 261-277 (2018) 